Pesq. Vet. Bras. 35(8):734-740, agosto 2015

DOI: $10.1590 / \mathrm{S} 0100-736 \mathrm{X} 2015000800005$

\title{
Occurrence of antibodies against Leptospira spp. in free-ranging wild canids from the Brazilian savanna ${ }^{1}$
}

\author{
Thaís C.S. Rodrigues ${ }^{2 *}$, André L.Q. Santos ${ }^{2}$, Anna M.C. Lima-Ribeiro ${ }^{3}$, Frederico \\ G. Lemos ${ }^{4,5}$, Fernanda C. Azevedo ${ }^{4}$, Ricardo C. Arrais ${ }^{4}$, Dayane O. Gomes ${ }^{3}$ \\ and Tatiane C.F. Tavares ${ }^{3}$
}

\begin{abstract}
Rodrigues T.C.S., Santos A.L.Q., Lima-Ribeiro A.M.C., Lemos F.G., Azevedo F.C., Arrais R.C., Gomes D.O. \& Tavares T.C.F. 2015. Occurrence of antibodies against Leptospira spp. in free-ranging wild canids from the Brazilian savanna. Pesquisa Veterinária Brasileira 35(8):734-740. Laboratório de Ensino e Pesquisa em Animais Selvagens, Universidade Federal de Uberlândia, Avenida Amazonas 2245, Jardim Umuarama, Uberlândia, MG 38405-302, Brazil. E-mail: thaiscarneiro_25@hotmail.com

The Brazilian savanna, also known as Cerrado, is one of the world's richest and most ecologically invaluable tropical savanna regions. There are few studies in Brazil about the diseases that affect the wild canids of this biome, which may be harmful to wildlife populations and public health. The aim of this study was to evaluate the occurrence of antibodies against Leptospira spp. in three Cerrado wild canids species using the microscopic agglutination test (MAT). Serum samples were tested from 19 crab-eating foxes (Cerdocyon thous), 14 maned wolves (Chrysocyon brachyurus), and seven hoary foxes (Lycalopex vetulus), all free-ranging animals found in the municipalities of Araguari and Uberlândia, Minas Gerais State, and Cumari, Goiás State, Brazil. Fourteen (35\%) of these samples were seropositive. The most frequent serovars detected in the samples were Copenhageni and Hardjo, but reactions to the serovars Autumnalis, Grippotyphosa, Hebdomadis, Wolffi, and Icterohaemorrhagiae also occurred. Notwithstanding other reported results, this study is the first to report the presence of antibodies against Leptospira spp. in L. vetulus. The three species of wild canids examined may act as potential hosts for several serovars of leptospira in Brazil's savanna environment.
\end{abstract}

INDEX TERMS: Carnivores, Cerdocyon thous, Chrysocyon brachyurus, Lycalopex vetulus, conservation, leptospirosis.

RESUMO.- [Ocorrência de anticorpos contra Leptospira spp. em canídeos selvagens de vida livre do cerrado brasileiro.] 0 cerrado é a mais diversificada savana tropical do mundo e constitui grande importância ecológica.

\footnotetext{
${ }^{1}$ Received on July 16, 2014.

Accepted for publication on May 13, 2015.

${ }^{2}$ Laboratório de Ensino e Pesquisa em Animais Selvagens (Lapas), Universidade Federal de Uberlândia (UFU), Avenida Amazonas 2245, Jardim Umuarama, Uberlândia, MG 38405-302, Brazil. *Corresponding author: thaiscarneiro_25@hotmail.com

${ }^{3}$ Laboratório de Doenças Infectocontagiosas, UFU, Rua Ceará s/n, Bloco 2D, Sala 33, Campus Umuarama, Uberlândia, MG 38405-315.

${ }^{4}$ Programa de Conservação Mamíferos do Cerrado (PCMC), Rua Vereador Nicomedes Nunes 135/casa 10, Bosque, Araguari, MG 38446-000, Brazil.

${ }^{5}$ Departamento de Ciências Biológicas, Universidade Federal de Goiás (UFG), Campus Catalão, Av. Lamartine P. Avelar 1120, Bloco K, Sala 7, Setor Universitário, Catalão, GO 75704-20, Brazil.
}

Ainda assim, são poucos os estudos realizados no Brasil a respeito das doenças que acometem os canídeos desse bioma, o que causa prejuízos à população de animais selvagens e à saúde pública. Essa pesquisa foi realizada com o objetivo de avaliar a ocorrência de anticorpos contra Leptospira spp. em três espécies de canídeos selvagens do cerrado brasileiro utilizando o teste de soroaglutinação microscópica (SAM). Foram testadas amostras de soro sanguíneo de 19 cachorros-do-mato (Cerdocyon thous), 14 lobos guarás (Chrysocyon brachyurus) e sete raposas-do-campo (Lycalopex vetulus) de vida livre das regiões de cerrado de Araguari e Uberlândia, MG, e Cumari, GO. Dessas 40 amostras, 14 (35\%) foram soropositivas. Os sorovares detectados com maior frequência foram Copenhageni e Hardjo, porém evidenciou-se também reação aos sorovares Autumnalis, Grippotyphosa, Hbedomadis, Wolffi e Icterohaemorrhagiae. Esse trabalho foi o primeiro a relatar a presença de anticorpos anti-Leptospira spp. 
em L. vetulus e verificou-se que as três espécies de canídeos utilizadas nessa pesquisa podem atuar como possíveis hospedeiros de diversos sorovares de leptospiras no ambiente de cerrado.

TERMOS DE INDEXAÇÃO: Carnívoros, Cerdocyon thous, Chrysocyon brachyurus, Lycalopex vetulus, conservação, leptospirose.

\section{INTRODUCTION}

The Brazilian Cerrado is the most diverse tropical savanna in the world (Klink \& Machado 2005) and the second largest biome in Brazil. It extends over eight Brazilian states, predominantly Goiás (GO) and Minas Gerais (MG) (Borlaug 2002). Characterized by enormous ranges of plant and animal biodiversity, this biome is home to 251 mammal species (Paglia et al. 2012). However, despite its foremost ecological importance, it is one of the most threatened biomes in the country (Brasil 2012) and in the world (Myers 2000), which makes it a hotspot.

Starting in the 19th century, large parts of the Cerrado began to be converted to agriculture (mainly monocultures in the last 20 years) and extensive cattle ranching, thereby restricting available areas for wildlife and reducing biodiversity of this ecosystem (Brasil 1999). In fact, over $72 \%$ of the species listed in the Red Book of Brazilian Endangered Fauna are native to the Cerrado and Atlantic Rainforest (Brasil 2012). Fragmentation and habitat loss represent a serious threat, particularly to carnivores, due their high spatial requirements for feeding and reproduction (Massara 2009, Wilson \& Mittermeir 2009). Among these species, canids are under particular threat since they occur in both highly preserved and secondary areas, reducing the distance between wildlife and humans (Lemos et al. 2011). According to these authors, this group also faces the risk of becoming roadkill, of being poisoned, and attacked by domestic dogs as a result of conflicts between humans and carnivores.

Degradation of natural habitats increases the proximity of wildlife to human populations and domestic animals, favoring the transmission of diseases. Indeed, Curi (2005) stated that infectious diseases are particularly relevant as factors that threaten the conservation of wild canids of the Cerrado. Maia \& Gouveia (2002) reported that 9\% of captive maned wolf (Chrysocyon brachyurus) deaths in Brazil (between 1989 and 1998) were caused by infectious diseases. However, studies in Brazil about diseases that may affect these animals are still scanty, although such diseases have the potential to seriously harm not only to wildlife populations but also human public health. Canids can act as important sources of infection and carriers of pathogens that can affect the health of human and other animal species (Aguiar 2000).

It is known that wild canids are potentially susceptible to common diseases and zoonosis that affect domestic dogs (Canis familiaris) (Fowler 1986, Deem \& Emmons 2005). There are reports of maned wolves suffering from distemper (Maia \& Gouveia 2002), crab-eating foxes (Cerdocyon thous), maned wolves, and hoary foxes (Lycalopex vetulus) affected by parvovirus (Mann et al. 1980, Curi 2005, Jorge
2008, Maldonado 2009), leishmaniasis in crab-eating foxes (Courtenay et al. 1996, Courtenay 2002), and reports of maned wolves seropositive for Toxoplasma gondii (Proença 2007). In addition, the crab-eating fox has been implicated as the main reservoir of rabies virus among wild canid species in northeast Brazil (Carnieli et al. 2008).

Among these diseases, leptospirosis is an infectious disease of major importance to public health and can potentially infect wild canids from the Cerrado. This disease has a complex epidemiological cycle that involves humans and domestic and wild animals (Brasil 1995). In general, wild animals behave as asymptomatic carriers of the pathogen and may be affected by several serovars of Leptospira spp., acting as perennial sources of infection for humans and other animals (Santa Rosa et al. 1980, The World Zoo 1993).

Epidemiological studies of Leptospira spp. in wild canids are rare, particularly in free-ranging populations (Lins \& Lopes 1984, Girio et al. 1999), and little is known about leptospirosis in animals of the savanna. Therefore, the present study aimed to evaluate the occurrence of antibodies against Leptospira spp. in three free-ranging wild canid species of the Brazilian savanna and to identify the most frequent serovars in these animals.

\section{MATERIALS AND METHODS}

\section{Study area, captures and sample collection}

The occurrence of antibodies against Leptospira spp. in three wild canid species of the Brazilian savanna was evaluated using the microscopic agglutination test (MAT). Serum samples were tested from 19 crab-eating foxes (Cerdocyon thous), 14 maned wolves (Chrysocyon brachyurus) and seven hoary foxes (Lycalopex vetulus), all free-ranging animals from savanna regions in the municipalities of Araguari (UTM 22K 785758/7939098) and Uberlândia (UTM 22K 786826/7905936), state of Minas Gerais (MG), and Cumari (UTM 22K 805816/7964233), state of Goiás (GO). Most of the savanna areas in Minas Gerais are cultivated with soy bean and corn, while pastureland (Brachiaria sp.) and cattle farms cover large areas of Goiás, although small patches of cerrado still exist (Lemos et al. 2011).

The serum samples came from the collection of the Wildlife Teaching and Research Laboratory (LAPAS) at the Federal University of Uberlândia (UFU) and from the research group Programa de Conservação Mamíferos do Cerrado (Cerrado Mammals Conservation Program) (PCMC, based at the Federal University of Goiás / Catalão. All the samples were collected humanely for purposes other than that of this study and were stored at about $-22^{\circ} \mathrm{C}$. No animal was handled specifically for this study. The LAPAS samples were collected from free-ranging wild animals found in residential areas or injured animals seized by the Brazilian Institute of Environment and Renewable Natural Resources (IBAMA) and the Environmental Police.

The samples from PCMC collection were taken from animals captured between 2008 and 2011 (captures carried during dry and rainy periods) using galvanized wire mesh traps baited with sardines and boiled chicken, and were part of a broader study on the ecology and epidemiology of the three canid species. Animals were immobilized with an intramuscular injection of zolazepam and tiletamine $\left(\right.$ Zoletil $^{\circledR}$ ) at dosages of $3-20 \mathrm{mg} / \mathrm{kg}$, according to the target species. The anesthetized animals were marked with ear-tags for individual identification and fitted with VHF radio collars. Blood samples were taken by cephalic venipuncture and 
stored in Vacutainer ${ }^{\circledR}$ tubes for serological tests. The animals were released at the capture site after recovering completely from anesthesia.

All the animal handling procedures followed the guidelines of the American Society of Mammalogists for the use of wild mammals in research (Gannon \& Sikes 2007). Permission for capture and sample collection of wild carnivores was given by IBAMA (SISBIO license number 14576-2).

\section{Serologic studies}

MAT was conducted at the Laboratory of Infectious Diseases of UFU, using a panel of 14 serovars: Australis, Autumnalis, Bataviae, Bratislava, Canicola, Copenhageni, Grippotyphosa, Hardjo, Hebdomadis, Icterohaemorrhagiae, Pomona, Pyrogenes, Tarassovi and Wolffi. The test was performed according to Brasil (1995) and samples with more than $50 \%$ agglutination were considered reagent. The titer of a serum was the highest dilution that agglutinated.

\section{RESULTS}

Fourteen $(35 \%)$ of the 40 blood serum samples of wild canids analyzed in this study were positive by MAT and all the species had reagent samples. Reactions to Autumnalis, Copenhageni, Grippotyphosa, Hardjo, Hebdomadis, Wolffi, and Icterohaemorrhagiae serovars were observed. Antibodies against the serovars Copenhageni and Hardjo occurred more frequently in the positive samples. No sample reacted positively to the serovars Bataviae, Bratislava, Pyrogenes, Australis, Tarassovi, Pomona, and Canicola.

Antibodies against serovars Hebdomadis and Wolffi were detected in four samples each, while antibodies to the serovar Grippotyphosa occurred in three samples. Only one sample was positive for each of the serovars Autumnalis and Icterohaemorrhagiae, so these were the least frequent serovars among the positive animals. The results are summarized in Table 1. The serological titers found in the positive samples ranged from 100 to 400 . The antibody titer that occurred at the highest frequency was 100 , followed by 200 and 400 (Table 2).

Table 1. Microscopic agglutination test results for the $\mathbf{4 0}$ samples of blood serum tested from wild canids from Brazilian savanna, according to species

\begin{tabular}{|c|c|c|c|c|c|}
\hline Species & $\begin{array}{c}\text { Tested } \\
\text { sample } \\
\text { number }\end{array}$ & $\begin{array}{l}\text { Positive } \\
\text { samples } \\
\text { number }\end{array}$ & $\%$ & Serovars & $\begin{array}{c}\text { Percentages } \\
\text { of each } \\
\text { serovar }(\%)\end{array}$ \\
\hline \multirow{7}{*}{$\begin{array}{l}\text { Cerdocyon } \\
\text { thous }\end{array}$} & 19 & 08 & 42.1 & Autumnalis & 12.5 \\
\hline & & & & Copenhageni & 37.5 \\
\hline & & & & Grippotyphosa & 37.5 \\
\hline & & & & Hardjo & 37.5 \\
\hline & & & & Hbedomadis & 37.5 \\
\hline & & & & Wolffi & 25 \\
\hline & & & & $\begin{array}{l}\text { Icterohae- } \\
\text { morrhagiae }\end{array}$ & 12.5 \\
\hline \multirow{5}{*}{$\begin{array}{l}\text { Crysocyon } \\
\text { brachyurus }\end{array}$} & 14 & 05 & 35.7 & Hardjo & 40 \\
\hline & & & & Wolffi & 20 \\
\hline & & & & Hbedomadis & 20 \\
\hline & & & & Copenhageni & 60 \\
\hline & & & & $\begin{array}{l}\text { Icterohae- } \\
\text { morrhagiae }\end{array}$ & 20 \\
\hline Lycalopex & 07 & 01 & 14.2 & Hardjo & 100 \\
\hline vetulus & & & & Wolffi & 100 \\
\hline
\end{tabular}

Table 2. Frequency of serovars detected in positive samples of blood serum of wild canids from the Brazilian savanna and serologic titers, according to species

\begin{tabular}{lccccc}
\hline Species & Serovars & Frequency & \multicolumn{3}{c}{ Titers } \\
\cline { 3 - 6 } Cerdocyon thous & & 100 & 200 & 400 \\
\hline & Autumnalis & 1 & - & - & 1 \\
& Copenhageni & 3 & 2 & 1 & - \\
& Grippotyphosa & 3 & 2 & 1 & - \\
& Hardjo & 3 & - & 2 & 1 \\
& Hbedomadis & 3 & 2 & 1 & - \\
& Wolffi & 2 & - & 1 & 1 \\
& Icterohae- & 1 & 1 & - & - \\
& morrhagiae & & & & \\
Crysocyon brachyurus & Hardjo & 2 & 1 & - & 1 \\
& Wolffi & 1 & - & 1 & - \\
& Hbedomadis & 1 & 1 & - & - \\
& Copenhageni & 3 & 3 & - & - \\
& Icterohae- & 1 & 1 & - & - \\
Lycalopex vetulus & morrhagiae & & & & - \\
& Hardjo & 1 & - & 1 & - \\
& Wolffi & 1 & - & 1 & -
\end{tabular}

\section{DISCUSSION}

This research showed that the three canid species under study had contact with Leptospira spp. in Brazilian savanna environments. Scientific studies on leptospirosis are beginning to be conducted on captive wild animals in Brazil (Guerra-Neto 2006). In general, higher percentages of wild canids positive to MAT have been reported in Brazilian Zoos than that observed in this study (Luna-Alvarez 1996, Lilenbaum et al. 2002, Esteves et al. 2005). This may be because zoo animals are kept in captivity and under more stressful epidemiological conditions than free-ranging animals and captivity favors the spread of diseases and pathogens.

The geographic and climate characteristics of each region in which this and other surveys were conducted must also be considered. Knowing that there is a higher incidence of leptospirosis in areas with high levels of rainfall (Batista et al. 2005), studies in these areas are expected to find a larger number of animals positive to MAT. However, this is not the case in the Brazilian savanna, which is characterized by marked dry and wet periods (Assad et al. 1993).

Reports of the presence of antibodies against Leptospira spp. in wild canids such as maned wolves and crab-eating foxes indicate a high frequency of infection in these animals. This applies to both free-ranging (Jorge 2008) and captive animals (Esteves et al. 2005). In free-ranging canids, this infection may be attributed to their territorial and dietary habits. The maned wolf, which is the largest member of the Canidae family in South America (Einsenberg \& Redford, 1999), travels distances of 21.7 to $132 \mathrm{~km}^{2}$ daily (Dietz 1984, Carvalho \& Vasconsellos 1995, Rodrigues 2002, Mantovani et al. 2007, Azevedo 2008). Crab-eating foxes and hoary foxes usually use smaller areas but also roam extensively through their territory (Juarez \& Marinho-Filho 2002, Courtenay et al. 2006).

The extensive wandering of these wild canids provides numerous possibilities of contact with domestic animals and synanthropic reservoirs, favoring the transmission of Leptospira spp. (Jorge 2008). Moreover, except for the hoary fox, crab-eating foxes and maned wolves have diets 
based on fruits and small mammals such as rodents and small marsupials (Jácomo et al. 2004, Ferreira-Silva \& Lima 2006, Dalponte 2009), which are the most important reservoirs of the pathogen (Faine et al. 1999). Hoary foxes are insectivorous carnivores that feed mainly on termites and other insects (Dalponte 1995, Juarez \& Marinho-Filho 2002, Dalponte 2009). Although they also consume small mammals, these do not represent the main diet of the species, although there are reports of hoary foxes scavenging on small domestic animals such as goats (Dalponte 1995), which also represents a risk of infection.

In this study, the serovars Copenhageni and Hardjo occurred more frequently in the wild canids under study. According to Faine et al. (1999), the serovar Copenhageni belongs to the serogroup Icterohaemorrhagiae and its main reservoirs are synanthropic rodents, which are a potential part of the food chain of these canids. Pimentel et al. (2009) attributed the presence of this serovar in a zoo in the state of Sergipe, Brazil, to the presence of rats (Rattus norvegicus) in the zoo environment, which confirms the possibility of contact between these rodents and canids.

It is noteworthy that, in Brazil, the serovar Copenhageni is imputed to be responsible for the most serious cases of human leptospirosis (Sakata et al. 1992, Brasil 2005). As wild canids come into increasing contact with areas inhabited by humans, we must be concerned with a possible transmission of pathogens between canids and humans. According to Figueiredo et al. (2009), the natural host of the serovar Hardjo is cattle. It is important to analyze the high frequency of the occurrence of this serovar in wild canids, since these wild animals are using livestock areas as their territory and are thus being exposed to infectious agents of domestic animals.

The serovars most commonly found in the animals of this study differ from those described as common for wild canids in other areas of Brazil. The serovars Castellonis, Cynopteri, Canicola, and Icterohaemorrhagiae have been reported as the main serovars in canids (Corrêa et al. 2004, Esteves et al. 2005), but were not found in all the species of our study. This may indicate that animals from the Cerrado are exposed to serovars different from those found in other Brazilian regions, and that these species can be reservoirs and hosts for a wide variety of serovars.

Studies conducted in Brazil show that some crab-eating foxes are positively reactive to several serovars of Leptospira spp., as observed in this study as well as by Souza-Júnior, Lobato \& Lobato (2006) and Jorge (2008). The serovars Autumnalis, Copenhageni, and Grippotyphosa, found in crab-eating foxes in this research have also been reported in earlier studies (Esteves et al. 2005, Jorge 2008, Pimentel et al. 2009). Vieira (2009) also identified the serovar Hardjo-bovis, an indistinguishable subtype of the serovar Hardjo detected in this study, in the species. Reports of the serovars Wolfii and Icterohaemorrhagiae in crab-eating foxes were not found, so this represents the first record. Serovars other than those detected in this study have been described in Cerdocyon thous (Corrêa et al. 2004, Souza-Júnior et al. 2006, Jorge 2008, Ullmann et al. 2012) (Table 3).
In the species $C$. brachyurus, the serovars found in this study differ from those described earlier (Deem \& Emmons 2005, Esteves et al. 2005, Jorge 2008, Ullmann et al. 2012). Only the serovar Icterohaemorrhagiae had already been reported in maned wolves in a national park in Bolivia (Deem \& Emmons 2005) (Table 4). Diniz, Lazzarini \& Angelo (1999) conducted a retrospective study of maned wolves in the São Paulo Zoo and reported that in 30 years, $2 \%$ of the animals died due to nephritis and epileptiform convulsions caused by Leptospira spp. Esteves et al. (2005) also discussed the possibility of a maned wolf death in the Uberaba Zoo due to leptospirosis, reporting interstitial nephritis and hemorrhagic gastroenteritis as pathological findings. An individual of the same species inhabiting the same enclosure where the animal died had antibodies against Leptospira spp.

There are no studies about the occurrence of leptospirosis in Lycalopex vetulus. Azevedo et al. (2009) sampled what they believed to be 60 hoary foxes in the state of Paraíba, but it is now known that those animals were misidenti-

Table 3. Comparison of serovars detected in Crab-eating foxes (Cerdocyon thous) in this study and serovars reported in other studies for this species

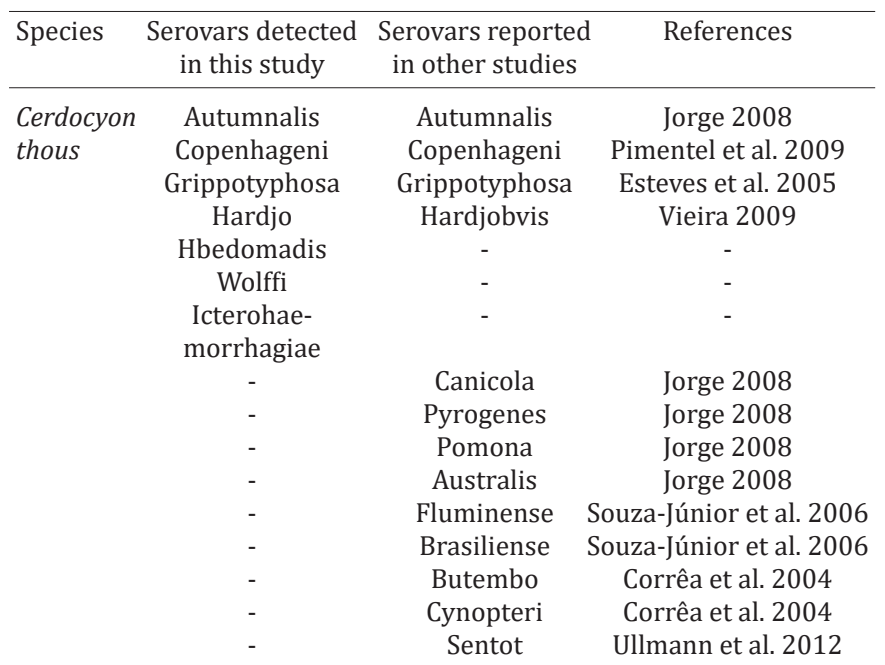

Table 4. Comparison of serovars detected in Maned wolves (Chrysocyon brachyurus) in this study and serovars reported in other studies for this species

\begin{tabular}{|c|c|c|c|}
\hline Species & $\begin{array}{l}\text { Serovars detected } \\
\text { in this study }\end{array}$ & $\begin{array}{l}\text { Serovars reported } \\
\text { in other studies }\end{array}$ & References \\
\hline Chrysocyon & Hardjo & - & - \\
\hline \multirow[t]{10}{*}{ brachyurus } & Wolffi & - & - \\
\hline & Hbedomadis & - & - \\
\hline & Copenhageni & - & - \\
\hline & $\begin{array}{l}\text { Icterohae- } \\
\text { morragiae }\end{array}$ & $\begin{array}{l}\text { Icterohae- } \\
\text { morragiae }\end{array}$ & Deem \& Emmons 2005 \\
\hline & - & Canicola & $\begin{array}{c}\text { Jorge 2008, } \\
\text { Esteves et al. 2005, } \\
\text { Ullmann et al. } 2012\end{array}$ \\
\hline & - & Pyrogenes & Jorge 2008 \\
\hline & - & Autumnalis & Jorge 2008 \\
\hline & & Ballum & Deem \& Emmons 2005 \\
\hline & & Grippotyphosa & Deem \& Emmons 2005 \\
\hline & & Szwajizak & Deem \& Emmons 2005 \\
\hline
\end{tabular}


fied. Although they were seronegative, these animals were crab-eating foxes. Therefore, this is the first report of the presence of antibodies against Leptospira spp. in Lycalopex vetulus in Brazil.

An individual of Lycalopex gymnocercus, phylogenetically close to L. vetulus, was described by Fiorello et al. (2007) as a host of serovar Grippotyphosa. Our new report adds information to other studies conducted in Brazil that describe the hoary fox as a potential reservoir of domestic or zoonotic pathogens, such as rabies virus (Gomes 2004, Silva et al. 2009).

Although the crab-eating fox is considered of Least Concern by the International Union for Conservation of Nature (IUCN) and the last Brazilian specialists evaluation (Beisiegel et al. 2013), the maned wolf is considered Vulnerable and at risk of extinction (IUCN 2012) in the coming decades. The maned wolf is also listed as vulnerable on the Red List of Brazilian Endangered Species, while the crab-eating fox is not listed (Brasil 2012, Paula et al. 2013).

As for the hoary fox, albeit listed as of Least Concern by the IUCN (2012), the species is considered Vulnerable to extinction (Lemos et al. 2013) and is important to note that it is the only Brazilian endemic carnivore and one of the world's seven least studied canids, according to the Canid Specialist Group of the IUCN. In Brazil, the species is described on the Paraná and São Paulo State Red Lists as Vulnerable (Mikich \& Bérnils 2004, Lemos \& Azevedo 2009). In the state of Minas Gerais, although it is not included in the Biodiversitas Online Red List (2012), Chiarello et al. (2008) consider the species Endangered in the state. Therefore, in view of the paucity of available data on the species' population dynamics, health, and conservation status, and taking into account the current scenario of Cerrado destruction by agricultural policies, all information about the hoary fox is important to ensure its conservation and a better understanding of this species.

The high frequency of low titers found in this study is common in most studies (Girio et al. 2004, Esteves et al. 2005, Souza-Júnior et al. 2006, Silva et al. 2010). Wild carnivores are sentinels for leptospirosis (Millán et al. 2009), indicating the occurrence of the disease in the environment. This research found that leptospirosis occurs in the Brazilian savanna and that wild canids are possible hosts. Understanding the occurrence of leptospirosis in these species is vital to assess the risks posed by this disease in these canids and to ensure the long-term survival of these species. These data may also provide a better understanding of the role of wild canids in the epidemiological context of leptospirosis in the Cerrado.

Acknowledgements.- The authors acknowledge the support offered by the Federal University of Uberlândia (UFU), Conselho Nacional de Pesquisa (CNPq), Fundação de Amparo à Pesquisa em Minas Gerais (Fapemig) and Coordenação de Aperfeiçoamento de Pessoal de Nível Superior (CAPES) to which we are grateful for. We are in debit with Consórcio Capim Branco de Energia (CCBE), Neotropical Grassland Conservancy (NGC), Idea Wild and Smithsonian Institution for supporting Programa de Conservação Mamíferos do Cerrado through equipments and funding, and the Centro Nacional para Pesquisa e Conservação de Mamíferos Carnívoros (CENAP/ICMBio) for support field veterinarian and supplies.

\section{REFERENCES}

Aguiar L.M.S. 2000. Comunidades de morcegos do Cerrado no Brasil Central. Tese de Doutorado em Ecologia, Universidade de Brasília, Brasília, DF. 162p.

Assad E.D., Sano E.E., Meirelles M.L. \& Moreira L. 1993. Estruturação de dados geoambientais no contexto de microbacia hidrográfica, p.89-108. In: Sistema de Informações Geográficas: aplicações na agricultura. Embrapa-CPAC, Planaltina.

Azevedo F.C. 2008. Área de vida e organização espacial de lobos-guará (Chrysocyon brachyurus) na região do Parque Nacional da Serra da Canastra, Minas Gerais, Brasil. Dissertação de Mestrado em Ecologia, Manejo e Conservação da Vida Silvestre, Universidade Federal de Minas Gerais, Belo Horizonte. 104p.

Azevedo S.S., Silva M.L.C.R., Batista C.S.A., Gomes A.A.B., Vasconcellos A.S. \& Aves C.J. 2009. Anticorpos anti Brucella abortus, anti Brucella canis e anti Leptospira spp. em raposas (Pseudalopex vetulus) do semiárido paraibano, Nordeste do Brasil. Ciência Rural, Santa Maria, Online.

Batista C.S.A., Alves C.J., Azevedo S.S., Vasconcellos A.S., Morais Z.M., Clementino I.J., Alves F.A.L., Lima F.S. \& Araújo-Neto J.O. 2005. Soroprevalência e fatores de risco para leptospirose em cães de Campina Grande, Paraíba. Arq. Bras. Med. Vet. Zootec. 57(2):179-185.

Beisiegel B.M., Lemos F.G., Azevedo F.C., Queirolo D. \& Jorge R.S.P. 2013. Avaliação do risco de extinção do Cachorro-do-mato Cerdocyon thous (Linnaeus, 1766) no Brasil. Biodiversidade Brasileira, 3(1):138-145.

Borlaug N.E. 2002. Feeding a world of 10 billion people: the miracle ahead, p.29-60. In: Bailey R. (Ed.), Global Warming and Other Eco-Myths. Competitive Enterprise Institute, Roseville, USA.

Brasil 1995. Manual de Leptospirose. Programa Nacional de Leptospirose, Coordenação de Controle de Zoonoses e Animais, Fundação Nacional de Saúde, Centro Nacional de Epidemiologia, Ministério da Saúde. 2nd ed. Brasília, DF. 98p.

Brasil 1999. Ações prioritárias para Conservação da Biodiversidade do Cerrado e Pantanal, p.288-301. In: Workshop Ações Prioritárias para a Conservação da Biodiversidade do Bioma Cerrado, Ministério do Meio Ambiente, Brasília, DF.

Brasil 2005. Guia de Vigilância Epidemiológica: Leptospirose. Secretaria de Vigilância em Saúde, Ministério da Saúde, Brasília. Biblioteca Virtual do Ministério da Saúde <www.saude.gov.br/bvs> Acesso outubro 2012.

Brasil 2012. Livro Vermelho da Fauna Brasileira Ameaçada de Extinção. Instituto Chico Mendes de Conservação da Biodiversidade, Ministério do Meio Ambiente, Brasília, 1(2):39-155.

Carnieli J.R., Fahl W.O., Castilho J.G., Oliveira R.N.O., Macedo C.I.M., Durymanova E., Jorge R.S.P., Morato R.G., Spindola R.O., Machado L.M., As J.E.U., Carrieri M.L. \& Kotait I. 2008. Caracterization of Rabies Virus isolated from canids and identification of the main wild canid host in Northeastern Brazil. Virus Res. 131(1):33-46.

Carvalho C.T. \& Vasconcellos L.E.M. 1995. Disease, food and reproduction of the maned-wolf Chrysocyon brachyurus (Illiger) (Carnivora, Canidae) in southeast Brazil. Revta Bras. Zool. 12(3):627-640.

Chiarello A.G., Aguiar L.M.S., Cerqueira R., Melo F.R., Rodrigues F.H.G. \& Silva V.M.F. 2008. Mamíferos Ameaçados de Extinção no Brasil, p.681-885. In: Machado A.B.M., Drummond G.M. \& Paglia A.P. (Eds), Livro Vermelho da Fauna Brasileira Ameaçada de Extinção. Fundação Biodiversitas, Ministério do Meio Ambiente, Brasília.

Corrêa S.H.R., Vasconcellos A.S., Morais Z., Teixeira A.A., Dias R.A., Guimarães M.A.B.V., Ferreira F. \& Ferreira Neto J.S. 2004. Epidemiologia da Leptospirose em animais silvestres na Fundação Parque Zoológico de São Paulo. Braz. J. Vet. Res. Anim. Sci. 41(3):189-193.

Courtenay O., Santana E.W., Johnson P.J., Vasconcelos I.A.B. \& Vasconcelos A.W. 1996. Visceral leishmaniasis in hoary zorro Dusicyon vetulus: a case of mistaken identity. Transactions Royal Soc. Trop. Med. Hygiene 90(5):498-502.

Courtenay O., Quinnel R.J., Garcez L.M. \& Dye C. 2002. Low infectiousness of a wildlife host of Leishmania infantum: the crab-eating fox is not important for transmission. Parasitology 125(5):407-414. 
Courtenay O., MacDonald D.W., Gilingham S., Almeida G. \& Dias R. 2006. First observations on South America's largely insectivorous canid: the hoary fox (Pseudalopex vetulus). J. Zoology 268:45-54.

Curi N.H.A. 2005. Avaliação do estado de saúde e do risco de transmissão de doenças entre canídeos (Mammalia, Carnivora) silvestres e domésticos na região da Serra do Cipó, Minas Gerais: implicações para conservação. Tese de Doutorado em Zoologia de Vertebrados, Pontifícia Universidade Católica de Minas Gerais, Belo Horizonte. 100p.

Dalponte J.C. 1995. The Hoary fox in Brazil. Canid News 3:23-24.

Dalponte J.C. 2009. Lycalopex vetulus (Carnivora: Canidae). Mammalian Species, 847:1-7.

Deem S.L. \& Emmons L.H. 2005. Exposure of free-ranging maned wolves (Chrysocyon brachyurus) to infectious and parasitic disease agents in the Noel Kempff Mercado National Park, Bolivia. J. Zoo Wildl. Med. 36(2):192-197.

Dietz J.M. 1984. Ecology and Social Organization of the Maned Wolf (Chrysocyon brachyurus). Smithsonian Institution Press, Washington, DC. 51p.

Diniz L.S.M., Lazzarini S.M. \& Angelo M.J. 1999. Problemas médico veterinários em lobo-guará (Chrysocyon brachyurus) em cativeiro. Revta Educ. Contin. 2(2):34-42.

Einsenberg J.F. \& Redford K.H. 1999. Mammals of the Neotropics: Equador, Peru, Bolívia, Brasil. Vol.3. University of Chicago Press, Chicago. 609p.

Esteves F.M., Guerra-Neto G., Girio R.J.S., Silva-Vergara M.L. \& Carvalho A.C.F.B. 2005. Detecção de anticorpos para Leptospira spp em animais e funcionários do Zoológico Municipal de Uberaba, MG. Arqs Inst. Biológico, São Paulo, 72(3):283-288.

Faine S., Adler B., Bolin C. \& Perolat P. 1999. Leptospira and Leptospirose. 2nd ed. CRC Press, Boca Raton. 353p.

Ferreira-Silva E. \& Lima E.S. 2006. Termite predation by the hoary fox, Pseudalopex vetulus (Lund) (Carnivora, Canidae), in a pasture in Mato Grosso, Central Brazil. Mammalia 70(3/4):255-260.

Figueiredo A.O., Pellegrin A.O., Gonçalves V.S.P., Freitas E.B., Monteiro L.A.R.C., Oliveira J.M. \& Osório A.L.A.R. 2009. Prevalência e fatores de risco para a leptospirose em bovinos de Mato Grosso do Sul. Pesq. Vet. Bras. 29(5):375-381.

Fiorello C.V., Noss A.J., Deem S.L., Maffei L. \& Dubovi E.J. 2007. Serosurvey of small carnivores in the Bolivian Chaco. J. Wildl. Dis. 43(3):551-557.

Fowler M.E. 1986. Zoo and Wild Animal Medicine. 2nd ed. W.B. Saunders, Philadelphia, p.799-811.

Gannon W.L. \& Sikes R.S. 2007. Guidelines of the American Society of Mammalogists for the use of wild mammals in research. Animal Care and Use Committee. J. Mammalogy 88:809-823.

Girio R.J.S., Herrera R.C.P., Pereira F.J.G. \& Mathias L.A. 1999. Pesquisa de infecção por Leptospira interrogans em animais da região de Nhecolândia, no Pantanal do Mato Grosso do Sul. Arqs Inst. Biológico, São Paulo, 65:87.

Girio R.J.S., Pereira F.L.G., Marchiori Filho M., Mathias L.A., Herreira R.C.P., Alessi A.C. \& Girio T.M.S. 2004. Pesquisa de anticorpos contra Leptospira spp. em animais silvestres e em estado feral da região de Nhecolândia, Mato Grosso do Sul, Brasil: utilização da técnica de imuno-histoquímica para detecção do agente. Ciência Rural 34(1):165-169.

Gomes A.A.B. 2004. Epidemiologia da raiva: caracterização de vírus isolados de animais domésticos e silvestres do semi-árido paraibano da região de Patos, Nordeste do Brasil. Tese de Doutorado em Epidemiologia Experimental e Aplicada às Zoonoses, Universidade de São Paulo, São Paulo, SP. 107p.

Guerra-Neto G. 2006. Frequência de anticorpos contra Leptospira spp. em felídeos neotropicais em cativeiro no Brasil. Dissertação de Mestrado em Medicina Veterinária, área de Patologia Animal, Universidade Estadual Paulista, Campus de Jaboticabal, Jaboticabal, SP. 50p.

IUCN-WCMC 2012. UNEP-WCMC Species Database: Cites-listed Species $<$ http://www.cites.org/eng/resources/species.html> Accessed October 18, 2012.

Jácomo A.T.A., Silveira L. \& Diniz-Filho J.A.F. 2004. Niche separation between the maned wolf (Chrysocyon brachyurus), the crab-eating fox (Dusicyon thous) and the hoary fox (Dusicyon vetulus) in central Brazil.
J. Zoology 262:99-106.

Jorge R.S.P. 2008. Caracterização do estado sanitário dos carnívoros selvagens da RPPN SESC Pantanal e de animais domésticos da região. Tese de Doutorado em Epidemiologia Experimental e Aplicada a Zoonoses. Universidade de São Paulo, São Paulo, SP. 105p.

Juarez K.M. \& Marinho-Filho J. 2002. Diet, habitat use and home ranges of sympatric canids in central Brazil. J. Mammalogy 83(4):925-933.

Klink C.A. \& Machado R.B.A. 2005. Conservação do Cerrado Brasileiro. Megadiversidade 1(1):148-155.

Lemos F.G. \& Azevedo F.C. 2009. Lycalopex vetulus (Lund, 1842), p.61. In: Bressan P.M., Kierulff M.C.M. \& Sugieda A.M. (Eds), Fauna Ameaçada de Extinção no estado de São Paulo: Vertebrados. Secretaria do Meio Ambiente, Fundação Parque Zoológico de São Paulo, São Paulo, SP, 645p.

Lemos F.G., Azevedo F.C.A., Costa H.C.M. \& May Junior J.A. 2011. Human threats to Hoary and Crab-eating foxes in central Brasil. Canid News 14(2) [online]. URL <http:/ /www.canids.org/canidnews/13/Hoary_ and_crabeating_foxes_in_Brazil.pdf>

Lemos F.G., Azevedo F.C., Beisiegel B.M., Jorge R.P.S., Paula R.C., Rodrigues F.H.C. \& Rodrigues L.A. 2013. Avaliação do risco de extinção da Raposa-do-campo Lycalopex vetulus (Lund, 1842) no Brasil. Biodiversidade Brasileira 3(1):160-171.

Lilenbaum W., Monteiro R.V., Ristow P., Fráguas S., Cardoso V.S. \& Fedullo L.P.L. 2002. Leptospirosis antibodies in mammals from Rio de Janeiro Zoo, Brazil. Res. Vet. Sci. 73(3):319-321.

Lins Z.C. \& Lopes M.L. 1984. Isolation of Leptospira from wild forest animals in Amazonian Brazil. Transactions Royal Soc. Trop. Med. Hygiene 78(1):124-126.

Luna-Alvarez M.A., Moles-Cervantes L.P., Torres-Barranca J.I. \& Gual-Sill F. 1996. Serological survey of leptospirosis in captive wildlife at the Chapultepec Zoo in Mexico City. Veterinaria (Mex.) 27(3):229-234.

Maia O.B. \& Gouveia A.M.G. 2002. Birth and mortality of Maned Wolves Chrysocyon brachyurus (Illiger, 1811) in captivity. Braz. J. Biology 62(1):25-32.

Maldonado C.G. 2009. Avaliação da Prevalência Viral em Carnívoros no Sítio Moura-Barrancos: implicações de Conservação. Dissertação de Mestrado em Biologia da Conservação, Universidade de Lisboa. Lisboa, Portugal. 55p.

Mann P.C., Bush M., Apeerl M.J.G., Beehler B.A. \& Montali R.J. 1980. Canine parvovirus in South American canids. J. Am. Vet. Med. Assoc. 177(9): 779-783.

Mantovani J.E., Mattos P.S.R., Santos J.E. \& Pires J.S.R. 2007. Sensoriamento remoto e radiotelemetria no estudo de padrões de uso da paisagem pelo lobo-guará no interior do estado de São Paulo. Proc. XIII Simpósio Brasileiro de Sensoriamento Remoto, Florianópolis, SC, p.4005-4012.

Massara R.L. 2009. Dieta, uso do habitat e endoparasitas fecais do lobo-guará na Serra da Calçada, região metropolitana de Belo Horizonte, Minas Gerais. Dissertação de Mestrado em Zoologia de Vertebrados, Pontifícia Universidade Católica de Minas Gerais, Belo Horizonte, MG. 68p.

Millán J., Candela M.G., López-Bao J.V., Pereira M., Jiménez M.A. \& León-Viscaíno L. 2009. Leptospirosis in wild and domestic carnivores in natural areas in Andalusia, Spain. Vector-Borne Zoonot. Dis. 9(5):549-554.

Mikich S.B. \& Bérnils R.S. 2004. Livro Vermelho da Fauna Ameaçada no Estado do Paraná. Governo do Paraná, Curitiba, Brasil.

Myers N.R., Mittermeier A., Mittermeier C.G., Fonseca G.A.B. \& Kent J. 2000. Biodiversity hotspots for conservation priorities. Nature 403:853-858.

Paglia A.P., Fonseca G.A.B., Rylands A.B., Hermann G., Aguiar L.M.S., Chiarello A.G., Leite Y.L.R., Costa L.P., Siciliano S., Kierulff M.C.M., Mendes S.L., Tavares V.C., Mittermeier R.A. \& Patton J.L. 2012. Lista Anotada dos Mamíferos do Brasil: annotated checklist of Brazilian mammals. 2nd ed. Occasional papers in Conservation Biology No.6, Conservation International, Arlington, VA. 76p.

Paula R.C., Rodrigues F.H.G., Queirolo D., Jorge R.P.S., Lemos F.G. \& Rodrigues L.A. 2013. Avaliação do estado de conservação do Lobo-guará Chrysocyon brachyurus (Illiger, 1815) no Brasil. Biodiversidade Brasileira, 3(1):146-159. 
Pimentel J.S., Gennari S.M., Dubey J.P., Marvulo M.F.V., Vasconcellos A.S., Morais Z.M., Silva J.C.R. \& Evêncio Neto J. 2009. Inquérito sorológico para toxoplasmose e leptospirose em mamíferos selvagens neotropicais do Zoológico de Aracaju, Sergipe. Pesq. Vet. Bras. 29(12):1009-1014.

Proença L.M. 2007. Soroprevalência de doenças infecciosas caninas em populações de lobos guará (Chrysocyon brachyurus) e cachorros do mato (Cerdocyon thous) na Estação Ecológica de Águas Emendadas, DF. Dissertação de Mestrado em Biologia Animal, Universidade de Brasília, Brasília, DF. 41p.

Rodrigues F.H.G. 2002. Biologia e Conservação do Lobo-Guará na Estação Ecológica de Águas Emendadas, DF. Tese de Doutorado em Ecologia, Instituto de Biologia, Universidade Estadual de Campinas, Campinas, SP. 96p.

Sakata E.E., Yasuda P.H., Romero E.C., Silva M.V. \& Lomar A.V. 1992. Sorovares de Leptospira interrogans isolados de casos de leptospirose humana em São Paulo, Brasil. Revta Inst. Med. Trop. 34(3):217-221.

Santa Rosa C.A., Sulzer C.R., Yabaguita R.M. \& Silva A.S. 1980. Leptospirosis in wildlife in Brazil; isolation of serovars canicola, pyrogenes and grippotyphosa. Int. J. Zool. 7(1):40-43.

Silva M.L.C.R., Lima F.S., Gomes A.A.B., Azevedo S.S., Alves C.J., Bernardi F. \& Ito F.H. 2009. Isolation of rabies vírus from the parotid salivary glands of foxes (Pseudalopex vetulus) from Paraíba State, Northeastern Brazil. Braz. J. Microbiol. 40(3):446-449.

Silva C.S., Gírio R.J.S., Guerra Neto G., Brich M., Santana L.A.S., Amâncio F.H., Mariani J.R. \& Wessort P.M.F. 2010. Anticorpos anti-Leptospira spp. em animais selvagens do zoológico municipal de Ribeirão Preto, Estado de São Paulo, Brasil. Braz. J. Vet. Res. Anim. Sci. 47(3):237-242.

Souza-Júnior M.F., Lobato Z.I.P. \& Lobato F.C.F. 2006. Presença de anticorpos da classe IgM de Leptospira interrogans em animais silvestres do Estado do Tocantins. Revta Soc. Bras. Med. Tropical 39:292-294.

The World Zoo 1993. The world zoo conservation strategy: the role of the zoos and aquaria of the world in global conservation. The Captive Breeding Specialist Group IUCN/SSC, Organization-IUDZG, Chicago Zoological Society, IL. 76p.

Ullmann L.S., Ramiro Neto N.D., Teixeira R.H.F., Nunes A.V., Silva R.C., Pereira-Richini V.B. \& Langoni H. 2012. Epidemiology of leptospirosis at Sorocaba Zoo, São Paulo state, Southeastern Brazil. Pesq. Vet. Bras. 32(11):1174-1178.

Vieira A.S. 2009. Levantamento de Leptospira spp. em animais silvestres do Pantanal sul-matogrossense por meio de técnicas sorológicas e moleculares. Dissertação de Mestrado em Ciência Animal, Universidade Federal de Mato Grosso do Sul, Campo Grande, MS. 83p.

Wilson D.E. \& Mittermeier R.A. 2009. Handbook of the Mammals of the World. Vol.1. Carnivores. Lynx Editions, Barcelona. 